\title{
Grand Challenges (and Great Opportunities) in Sedimentology, Stratigraphy, and Diagenesis Research
}

\author{
David M. Hodgson ${ }^{1 *}$, Anne Bernhardt ${ }^{2}$, Michael A. Clare ${ }^{3}$, Anne-Christine Da Silva ${ }^{4}$, \\ Julie C. Fosdick ${ }^{5}$, Barbara Mauz ${ }^{6}$, Ivar Midtkandal ${ }^{7}$, Amanda Owen $^{8}$ and \\ Brian W. Romans ${ }^{9}$ \\ ${ }^{1}$ School of Earth and Environment, University of Leeds, Leeds, United Kingdom, ${ }^{2}$ Institute of Geological Sciences, Freie \\ Universität Berlin, Berlin, Germany, ${ }^{3}$ National Oceanography Centre, University of Southampton Waterfront Campus, \\ Southampton, United Kingdom, ${ }^{4}$ Départment de Géologie, Université de Liège, Liège, Belgium, ${ }^{5}$ Department of Geography, \\ University of Connecticut, Mansfield, CT, United States, ${ }^{6}$ Department of Geography and Geology, University of Salzburg, \\ Salzburg, Austria, ${ }^{7}$ Department of Geosciences, University of Oslo, Oslo, Norway, ${ }^{8}$ School of Geographical and Earth \\ Sciences, University of Glasgow, Glasgow, United Kingdom, ${ }^{9}$ Department of Geosciences, Virginia Tech, Blacksburg, VA, \\ United States
}

Keywords: sedimentology, stratigraphy, diagenesis, society, life, carbon, source-to-sink

\section{INTRODUCTION}

\section{OPEN ACCESS}

Edited and Reviewed by: Valerio Acocella, Università degli Studi Roma Tre, Italy

*Correspondence: David M. Hodgson d.hodgson@/eeds.ac.uk

Specialty section:

This article was submitted to Sedimentology, Stratigraphy and

Diagenesis,

a section of the journal

Frontiers in Earth Science

Received: 21 September 2018 Accepted: 02 October 2018

Published: 23 October 2018

Citation:

Hodgson DM, Bernhardt A, Clare MA, Da Silva A-C, Fosdick JC, Mauz B,

Midtkandal I, Owen A and Romans BW (2018) Grand Challenges (and Great Opportunities) in Sedimentology, Stratigraphy, and Diagenesis Research.

Front. Earth Sci. 6:173. doi: 10.3389/feart.2018.00173
The 7.6 billion people living on our planet face a number of pressing issues that include climate change, food and energy security, natural resource management, human health, clean water management, sustainable use of the oceans, building resilient infrastructure, and responsible production and consumption (UNSDGs, 2015). Many of these issues involve a better understanding of ancient, modern, and future process interactions at and below the Earth's surface. Particulate transport processes and fluxes are the key physical measures, and sedimentary successions form the critical archives, which permit investigations into the response of the planet's interconnected systems to climate change, and the triggers, magnitudes, and frequency of natural hazards. Advances in quantification and forecasting of particulate and pollutant transport across the land, the continental shelf, and in the deep-ocean are urgently required to improve societal resilience to these planetary changes and hazards. Given the lack of long-term ( $>100$ s of years) instrumental records and uncertainties in future Earth system behavior, analysis of both recent and ancient sedimentary archives is required to tackle these challenges. A number of questions arise when faced with attempting such reconstructions from depositional sequences. For instance, can we confidently attribute processes to the resultant sedimentary deposits? How can we establish a precise chronology for past events? How did past events respond to environmental controls? How complete are sedimentary sequences? What post-depositional processes may complicate their interpretation?

To address these questions we require a deep understanding of sedimentology, stratigraphy, and diagenesis. These disciplines will continue to play a key role in tackling present and future global challenges, yet many knowledge gaps still exist. Fundamental questions remain unresolved concerning the fluid dynamics of particulate suspensions, the interpretation of the stratigraphic record with regard to a changing Earth surface, and the range of processes and products that occur during and following deposition and burial. Furthermore, improved understanding of the generation, transport, and deposition of siliciclastic, carbonate, volcaniclastic, organic, and anthropogenic sediments across Earth's surface, and the response of sediment-routing systems to non-stationary changes, are crucial to resolve changes in particulate fluxes from 
continents to oceans over a range of timescales. Here, we aim to emphasize some of the major research areas where the sedimentology, stratigraphy, and diagenesis community must become a focal point for the interdisciplinary study required to advance our understanding of complex behaviors of the Earth system, and the surfaces of other planetary bodies (Figure 1). Given the breadth of depositional environments, processes, and archives available, we cannot cover all the challenges where sedimentologists, stratigraphers, basin analysts, and sedimentary geochemists can contribute; hence, the themes and examples identified herein cannot be comprehensive, and inevitably reflect the perspectives of the authors.

Technological advances make these exciting times for geoscientists studying Earth surface processes, their depositional products, and the interactions with the biosphere, hydrosphere, atmosphere, and lithosphere; from monitoring contemporary sediment transport processes to interpretation of sedimentary archives that record ancient environmental changes. We set out three research grand challenges: (1) Sedimentology and society; (2) Life and sediment interactions; (3) Sedimentary system responses to external forcings. Finally, we conclude our summaries of these cutting-edge research topics with a rallying call for the sedimentology, stratigraphy, and diagenesis research communities to (re)establish our position as integral to future interdisciplinary research.

The open access journal Frontiers in Earth Science: Sedimentology, Stratigraphy, and Diagenesis (SSD) is a new vehicle to enable our discipline to continue to grow, and reinvigorate these research areas as core geoscience disciplines. We intend that these themes will form the basis for special sessions at conferences, and to accrue open access thematic sets in the journal, which will reflect the central position of SSD research in the geosciences, and across interdisciplinary research programmes. We are open to receiving manuscripts from across the full breadth of Sedimentology, Stratigraphy, and Diagenesis research community.

\section{SEDIMENTOLOGY AND SOCIETY}

Understanding the societal impacts of, and improving resilience in response to, Earth surface processes requires advancing and applying process sedimentology research in a wide range of environments. An essential step in this aspiration is much closer collaboration with other disciplines, such as engineering, biological sciences, climate and ocean sciences, and social sciences. Indeed, ongoing anthropogenic activities, and associated accelerated changes in global climate and Earth system processes (Steffen et al., 2015), present numerous natural hazards that may be non-stationary over a range of timescales. One particular hazard is related to significant changes in the flux of sediment from continent to oceans, and the mixtures of particulates (e.g., microplastics, pharmaceuticals, pesticides) available for transport (e.g., Syvitski et al., 2005; Syvitski and Kettner, 2011; Zalasiewicz et al., 2016). Forecasting likelihood, and responses to a range of natural hazards and pollutants, is of particular relevance to developing countries. Small Island
Developing States are vulnerable due to their isolated locations, reliance upon local clean drinking water, unpolluted fisheries (Pelling and Uitto, 2001; Terry and Goff, 2012) and limited connection via seafloor cables to global communications that enable future economic development (Carter et al., 2014). Here, we consider the potential impact of sedimentological research, with potential for direct and immediate socio-economic benefits, in: (i) the forecast and impact of geohazards; (ii) the extraction, dispersal, and concentration of pollutants; and (iii) understanding of long-term carbon transfer and storage.

\section{Geohazards}

A wide range of geohazards directly and indirectly impact global communities. Many hazards require improved understanding of pre-requisite conditions, particulate erosion, and often complex but interlinked-transport processes (Gill and Malamud, 2016). The dispersal of particulates that are harmful to health can occur over many temporal and spatial scales. A major challenge in extending the historic archives of extreme natural hazards is confidently identifying the depositional signature that can be linked to a specific type of triggering-event. Does every major earthquake trigger a submarine landslide or a turbidity current (Sumner et al., 2013; Moernaut et al., 2014)? Does every convective storm cause a river to flood (e.g., Murphy et al., 2018)? Not necessarily. There are complicated combinations of factors that condition natural systems to respond catastrophically. Furthermore, better understanding of erosional processes, including flow-substrate interactions (see section Life and Sediment Interactions), and identification of hiatal periods when there is neither sedimentation nor erosion, is crucial to using the stratigraphic record to improve forecasting of hazardous events.

Sedimentary archives provide the main proxy to estimate recurrence rates of hazardous events-such as earthquakes, tsunamis, flooding, etc.-over time-scales that exceed historic records (Moernaut et al., 2014; Schillereff et al., 2014). However, to understand the full behavior of natural systems, and in particular non-stationary responses where the statistical mean and variance change with time (e.g., climate trends, seismic cycles), there is an urgent need to quantify probabilities of risks associated with geohazards over millennial and even longer scales. Hence, analysis of stratigraphic successions plays a key role in extending hazard catalogs, but at present there are many uncertainties as to whether we can reliably discern different types of events from deposits (and hence need to better understand the sedimentological processes that lead to their deposition), about the completeness of the stratigraphic record (erosion and hiatus), and about the effectiveness of different triggers given variable sediment supply rates in the past. Pancost (2017) summarizes the potential of ancient climatic changes recorded in stratigraphic successions to: (i) critically test climate models on which future projections are based; (ii) investigate the responses and impacts of changing climates on Earth system processes and ecosystem dynamics; and (iii) identify important processes that are not (adequately) incorporated into climate models. Without mitigation strategies, there will be profound societal impacts of changes associated with a changing climate. The forecast 


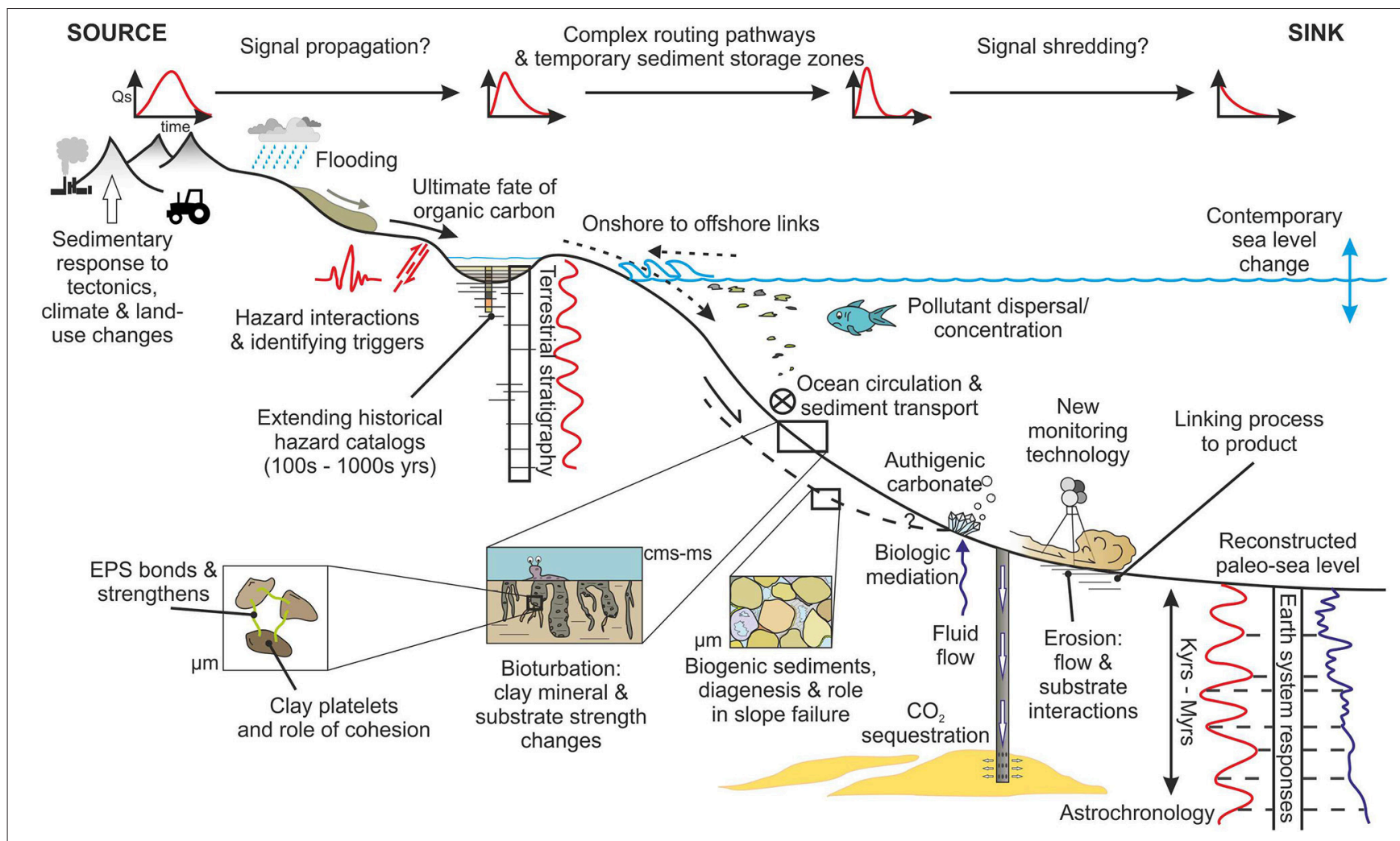

FIGURE 1 | Illustration of the range of sedimentological, stratigraphic, and diagenetic research themes highlighted by this article, Sedimentology and Society, Life and Sedimentology, and Sedimentary System Response to External Forcing. EPS, extracellular polymeric substances; Qs, sediment supply.

and mitigation of these changes is complicated, and requires interdisciplinary approaches, but will require detailed knowledge of sedimentary processes and interpretation of stratigraphic records.

For example, to forecast coastal realignment under projected accelerated sea-level rise and to improve resilience of coastal communities (fauna and humans) and critical seafloor infrastructure (e.g., offshore renewable interconnectors, oil, and gas decommissioning, telecommunications cables), requires understanding the dynamic interaction of changing topography with hydrodynamics and sediment availability (e.g., Chamberlain et al., 2018). The stratigraphic record of process responses to past changes in sea-level, whether the Holocene (e.g., Mellett et al., 2012), the last interglacial (e.g., Mauz et al., 2013; Hibbert et al., 2016) or in deeper time (e.g., Cattaneo and Steel, 2003), provides a means to support mitigation strategies for future sea-level rises. This is critical when only a few decimeters of sea-level rise can inundate large areas of coastal lowlands, particularly at river deltas which host seven times the global mean population density (Ericson et al., 2006). Therefore, a major challenge is to adequately resolve the rates and effects of past sea-level change on a decimeter-scale when analyzing sedimentary archives. A key advance will be to successfully link information from carbonate and siliciclastic records with geophysical models, and to integrate these tools in terms of sea-level cycles in order to support the modeling of geomorphological and sedimentary responses to future sea-level change.

Some geohazard assessments are closely tied to diagenetic understanding, both in uplifted sedimentary successions (telogenesis), such as carbonate dissolution and sinkholes, and processes soon after deposition. Early stage diagenetic changes (eogenesis), which include biological interactions (see section Life and Sediment Interactions), can affect the mechanical, and chemical properties of continental slope sediments, and as such influence the location and scale of hazards such as submarine landslides (e.g., Urlaub et al., 2018).

\section{Pollutant Dispersal}

The volume of pollutants dispersed through sediment-routing systems from fluvial, through shallow-marine segments and ultimately to deep-marine environments will continue to accelerate (e.g., Macdonald and Bewers, 1996; Zalasiewicz et al., 2016). Pollutants may consist of man-made materials, such as microplastics, pesticides, pharmaceuticals, or include the redistribution of detrital minerals and processed fragments from mining tailings or seabed dredging activity (e.g., Ellis and Ellis, 1994; Gwiazda et al., 2015; Ramirez-Llodra et al., 2015). The deep ocean is a sink for microplastics (e.g., Courtene-Jones et al., 2017) with direct impact on benthic ecosystems, and deeper burial through biological activity (Näkki et al., 2017). Changes in pollutant fluxes and mixes in the oceans urgently need to be 
quantified, and founded on a process basis to sustain and protect resources directly linked to human food and health. Monitoring and modeling contaminant transport, as well as unraveling physical process interactions that lead to, or set off, compound or cascading hazard events, requires improved understanding of key physiographic regimes, such as between rivers to coasts (Gill and Malamud, 2016). Sedimentologists and sediment geochemists need to be central to research on forecast and evaluation of pollutant transport processes and concentrations, pollutant interactions with the biosphere (see section Life and Sediment Interactions), and geochemical processes between pollutants and siliciclastic and carbonate sediment.

Recent technological developments provide new opportunities to directly observe particulate transport processes, quantify geohazard impacts, and monitor the dispersal of pollutants and transport of organic carbon at unprecedented spatial and temporal resolutions (e.g., Vrana et al., 2005; Azpiroz-Zabala et al., 2017). Despite significant recent advances in instrumentation, large uncertainties remain concerning the link between monitored transport processes and the resultant deposits, and how to robustly quantify key variables such as particle concentrations (Stevenson et al., 2018), substrate/flow/deposit interactions and entrainment. These are key issues that require focused and integrated research involving sedimentologists and stratigraphers.

\section{Carbon Transfer and Storage}

Improved understanding of carbon budgets/sinks through time (Galy et al., 2007; Owens et al., 2018), the prediction of natural carbon storage, and the design and implementation of carbon sequestration projects (e.g., Dewers et al., 2018), are intimately linked to advances in sedimentology, stratigraphy, and diagenesis. The flux of carbon along sediment routing systems with changing climate will have positive and negative feedbacks that are difficult to forecast. Studying the cycling of carbon within the context of sediment-routing systems (e.g., transfer between terrestrial and marine reservoirs; Leithold et al., 2016) and at a range of timescales is critical for a comprehensive understanding of arguably the most important element of the twenty-first century.

Carbon sequestration (or "negative emissions") will likely be a required component of broader climate-change mitigation to reduce the excess atmospheric $\mathrm{CO}_{2}$ in the Anthropocene Earth system (e.g., Rockström et al., 2016). Hydrocarbon extraction/management is ongoing and, even with aggressive decarbonisation of the energy mix, carbon storage will become increasingly important in the decades to come. The same skills used by sedimentologists, stratigraphers, and sedimentary geochemists for improved prediction and reduced risks in management of hydrocarbon reservoirs, and water aquifers, will be needed if introduction of carbon in the form of a fluid into the subsurface is successful (e.g., Cavanagh et al., 2010). In particular, the skills of sedimentary geochemists will be essential in understanding kinetics and products as new fluid mixes enter former hydrocarbon reservoirs (e.g., Armitage et al., 2010; Tambach et al., 2015), and will inform decision-making into the feasibility and longevity of $\mathrm{CO}_{2}$ sequestration projects.

\section{LIFE AND SEDIMENT INTERACTIONS}

The influence of life on sediments spans production processes through transport and deposition to postdepositional modifications. Improved understanding of biosphere interactions with sediments, and the precipitation of biologically-influenced chemical sediments, will help to constrain the flux and character of abiotic and biotic grains in all environments.

Interactions between life and sediment can impact Earthsurface topography, including resulting sediment production, erosion, transport, and deposition, and is a field of active and interdisciplinary research (e.g., Collins, 2004; Dietrich and Perron, 2006; Roering et al., 2010; Ulloa et al., 2015; Schaller et al., 2018). Constraining the influence of flora and fauna on the production and delivery of sediment from different bedrock and regolith, along sediment-routing systems, and into the deep ocean through geological time requires novel and interdisciplinary research, and close collaboration with paleobiologists, geochemists, geomorphologists, and landscape-evolution modelers. This research topic segues with the need for quantification of sediment flux (section Sedimentary System Response to External Forcings) to deepen our understanding of detailed sediment-production processes, and will enable more quantitative interpretation of paleoenvironmental changes from sedimentary archives. Furthermore, constraining interactions between biological and sedimentological processes into deep geological time will need to accommodate understanding of evolutionary change.

The marine biosphere is also a major control on subaqueous sedimentary and biochemical processes. Benthic and microbial organisms are abundant in cohesive sediments a meter or so below the seabed (Parkes et al., 2000; Murray et al., 2002), and can significantly modify the geomechanical properties of substrate. At cold seeps, bacteria can mediate the formation of authigenic carbonate crusts that host environmentally sensitive and isolated benthic communities that would otherwise not be found in the cold deep sea (e.g., Stakes et al., 1999; Aloisi et al., 2002; Jones et al., 2014). Sedimentological and diagenetic analysis of such authentic carbonates helps to understand how they formed, the rate of development, and to identify safe sites for seafloor infrastructure. In siliciclastic settings, bioturbation typically results in compaction and substrate strengthening; however it can also result in the weakening of substrates (Murray et al., 2002). Any geomechanical modification may promote or inhibit erosion, and thus affect the composition of overriding flows. How the rate and depth of substrate modification has changed through time will require collaboration with paleobiologists. Since a marked increase in the intensity and diversity of bioturbation in deep-sea substrates (the Great Ordovician Biodiversification event; Màngano et al., 2016), the diversity of deep-sea trace fossils has fluctuated. For example, some ichnotaxa have markedly increased their environmental range for some time periods (e.g., Cummings and Hodgson, 2011), and the burrowing depths of macrofauna is far greater than previously constrained (Cobain et al., 2018). Furthermore, changes in sediment mineralogy 
occur though ingestion and excretion by burrowing animals has been demonstrated experimentally (e.g., Needham et al., 2005), and biofilm formation from microfauna and burrowing macrofauna can pre-condition subsequent diagenetic processes and products (Dowey et al., 2012; Wooldridge et al., 2017). This demonstrates that life can have a profound post-depositional impact on sedimentary successions. Future advances to improve understanding of biological impacts on erosion, deposition, and eogenetic processes through geological time will require the integration of marine geology and biological datasets with ancient records across a wide range of environmental settings.

Extracellular polymeric substances (EPSs) are natural polymers secreted by microorganisms produced from cell lysis and adsorbed organic matter to form mixtures of complex high-molecular-weight (e.g., Sheng et al., 2010). Their composition and characteristics affect the formation of microbial aggregates (Lin et al., 2014), and other enigmatic (commonly lacustrine) carbonates, which is a major area of ongoing research (e.g., Bosence et al., 2015). In addition to bacterial precipitation and EPS, the impact of viruses on carbonate precipitation may have been under evaluated and needs reassessment (e.g., Lisle and Robbins, 2016; Perri et al., 2018). A recent advance in physical-chemical-biological interactions is the recognition that EPSs, and other cohesive fine-grained material, are major controls on sedimentary processes. Cohesive sediments and sticky substances, including EPS, impact the erodibility of substrate, and sediment transport and deposition processes (e.g., Malarkey et al., 2015; Lai et al., 2018; Lichtman et al., 2018). An associated advance is the understanding that many sedimentary processes involve mixed grain-size and grain-type flows (polydisperse), and challenge established bedform-phase diagrams that assume very narrow (monodisperse) grain-size distributions, leading to reanalysis of many sedimentary structures, and process interpretations (Baas et al., 2016).

\section{SEDIMENTARY SYSTEM RESPONSE TO EXTERNAL FORCINGS}

Sedimentologists are leading the re-appraisal of sedimentrouting systems, with an emphasis on source-to-sink configurations and functioning across a range of modern to deep timescales ( $>10^{5}-10^{6}$ year; e.g., Romans et al., 2016; Allen, 2017). A holistic perspective of sediment production, transport, and deposition is inherently integrative and fosters an interdisciplinary approach necessary to address important questions in the Earth Sciences. Advances in understanding the links between erosion-dominated catchments, through the fragmented depositional record of transfer zones, to the depositional record archived in sedimentary basins (Figure 1), have been supported by technological advances, such as singlegrain based geochronology (e.g., Lawton, 2014), cosmogenic radionuclide dating (e.g., Mason and Romans, 2018), lowtemperature thermochronologic estimates of long-term erosion rates (e.g., Carrapa, 2010), geophysical imaging of stratal geometries and sedimentary volumes (e.g., Covault et al., 2011), numerical modeling (e.g., Hawie et al., 2017), and unmanned aerial vehicle (UAV) and LiDAR technology (e.g., Buckley et al., 2010).

These technological advances in constraining timing and rates has led to quantification of sediment fluxes from source (catchments) to sink (sedimentary basins), which allows for examination of Earth surface change in response to external forcings. An emphasis on more complete sediment budgets, based on volume, and mass determination, instead of pointlocation sedimentation rates mitigates well-known issues related to stratigraphic incompleteness (Sadler, 1981; Sadler and Jerolmack, 2014). Moreover, the increased number of integrated onshore-to-offshore records have facilitated a more complete understanding of source-to-sink configurations (e.g., Clift, 2006; Sømme et al., 2009; Covault et al., 2011; Guillocheau et al., 2012; Richardson et al., 2017).

A recent focus among the Earth Science community has been on constraining the interactions and feedbacks between tectonic and climate processes at a range of spatial and temporal scales (e.g., Castelltort and Van Den Driessche, 2003; Armitage et al., 2011, 2013; Godard et al., 2013; Braun et al., 2015; Schlunegger and Castelltort, 2016). These studies complement traditional sequence-stratigraphic approaches that have emphasized accommodation signals by highlighting, and in some cases quantifying, the magnitude and variability of sediment delivery to a sedimentary basin. However, the quantification of responses to external forcings and environmental signal propagation at historic, millennial, and million-year timescales of the magnitude and timing of sedimentary system is in its infancy. For example, understanding if a climate signal is buffered or, in some cases, "shredded" (Jerolmack and Paola, 2010) en route to the stratigraphic record is critical if we are to use those archives to reconstruct past global warming events. To resolve these processes and controlling factors in the integrated sedimentary basin record requires the use of proxy records. The quantity and quality of proxy datasets are rapidly growing, including uplift and exhumation events in the sediment-source from high and low-temperature geochronology and numerical modeling, sediment-transport independent paleoclimate archives such as coral archives, pollen, and biomarkers. Sedimentary deposits proximal to major ice sheets have been shown to be valuable archives of the dynamics of these globally important features (Jaeger and Koppes, 2016). Other sedimentary archives with that may form more complete of environmental change remain underexploited, such as contourite drifts (e.g., Bahr et al., 2014), overbank deposits to submarine channel systems (e.g., Hansen et al., 2015; Hodgson et al., 2016), and submarine fans (e.g., Picot et al., 2016).

Improved constraints on the duration, and rates, of sedimentation in all archives necessitates integration with other Earth Science disciplines. A potentially rich area of collaboration is the integration of source-to-sink analysis with astrochronology. Identifying cycles within sedimentary successions, and tuning these to the astronomical target curves, has allowed calibration of most of the Cenozoic time scale 
(Hilgen et al., 2006), and permits the estimation and duration of sedimentary successions and rates of sediment accumulations. Earth's orbital parameters govern climatic patterns through seasonality and solar intensity. The recognition and impact of Milankovitch cycles have been reported in a wide range of environments from loess (Maher, 2016), evaporitic (Anderson, 1982), shallow lagoonal and reefal carbonates (De Vleeschouwer et al., 2015), deltaic (Marshall et al., 2017), turbiditic (Payros and Martínez-Braceras, 2014), and deep marine (Hinnov and Hilgen, 2012) records. However, advancements still need to be made in order to link with source-to-sink datasets. For example, understanding the link between the onset and termination of climatic events ("nodes") remain challenges due to issues of sensitivity and non-linearity of the proxy's response to the climate forcing.

Another important approach in this theme is the application and integration of landscape evolution models and stratigraphic/depositional models (e.g., Forzoni et al., 2014) to formulate working hypotheses of sedimentary system response to climate and tectonics that can be tested in the stratigraphic record. In addition to sedimentary signal propagation and response, the concepts of sedimentary system "sensitivity" (analogous to climate sensitivity) will become increasingly important. At shorter timescales, this research area is closely aligned to quantitative geomorphology and landscape-evolution modeling. If we want to advance source-to-sink studies, and understand how sedimentary successions record past changes in environmental conditions, we need to document geomorphic processes, and "read" stratigraphic archives to quantify paleoenvironmental change. One focus has been to derive scaling relationships between the onshore catchments and the offshore depositional sink (e.g., Sømme et al., 2009; Bhattacharya et al., 2016), which can be used to guide likely source-area characteristics from the depositional record in a semi-quantitative manner.

Lastly, at the sedimentary basin-scale, sedimentary archives chronicle the erosional history of their sediment sources and mechanisms of basin formation, offering invaluable information about tectonic histories and continent- or orogen-scale sediment dispersal patterns. New areas of research exploring interactions between tectonics and sedimentation and refined analytical methods for linking sources to their sinks will continue to lead advances in basin studies. This is reflected in the central role of stratigraphers when constraining large-scale and long-term crustal deformation patterns (Fosdick et al., 2015).

\section{CONCLUSIONS, AND A RALLYING CALL}

These are exciting times for sedimentologists, stratigraphers, and sediment geochemists! There is an unprecedented breadth of techniques and tools available. For example, novel age-dating approaches that allow better links between landscape evolution and the stratigraphic record; there is widespread availability of huge topographic, bathymetric, and seismic reflection datasets; new technology permits the monitoring of geophysical flows at high fidelity, which are supported by advances in numerical and analog modeling capabilities. The opportunities to monitor modern systems in detail, and to extract more information from ancient archives, have never been greater, or more pertinent in order to better understand and predict future risks facing society.

SSD research is central to many societally-relevant problems in addition to fundamental questions in the Earth Sciences. We need to communicate the importance of SSD research in the context of all the grand challenges in the Earth Sciences that, in one way or another, use sediments and the stratigraphic record. To lead these advances as an interdisciplinary community, we need to actively engage, or reengage, with engineering, biosciences, climate sciences, environmental economists, and more. An ongoing challenge will be to demonstrate the continued need to invest in SSD research ideas, technology, and training of early career personnel to develop the next generation of SSD-facing geoscientists. There might be (major) uncertainties in understanding of particulate transport and deposition, in stratigraphic shapes and patterns, in the exact products of flows of different fluid-sediment mixes in a range of media, but our knowledge will lead to more accurate evaluation of data, of models, of output. SSD is a cornerstone of geochemical, paleontological, and paleoclimatic research, and is central to interpreting the stratigraphic record of past environmental change, and to better forecast how sedimentary systems may respond to our changing climatic conditions and sea-level state. Research excellence in SSD, in description and interpretation, must be integral to associated disciplines.

The SSD section of Frontiers in Earth Science will publish highquality papers on all aspects of theoretical and applied research that use field, remote sensing, geophysical, and analog and modeling approaches. Our ultimate goal is to accelerate progress in interdisciplinary research where sedimentary, stratigraphic and diagenetic research is a central component. We welcome high quality publications across the breadth of SSD research. This includes data-rich case studies when clearly placed in the context of the wider research landscape. Our ambition is that this new journal will help to reaffirm the critical need for excellent SSD research to underpin geochemical, paleoclimatic, paleontological, and geoengineering studies, and to lead advances needed for many of the grand challenges facing Earth Science research.

\section{AUTHOR CONTRIBUTIONS}

$\mathrm{DH}$ is lead author, with major contributions from $\mathrm{AB}, \mathrm{MC}$, A-CDS, JF, BM, IM, AO, and BR. MC designed and DH drafted Figure 1.

\section{ACKNOWLEDGMENTS}

$\mathrm{DH}$ acknowledges support from the NERC Yorkshire Integrated Catchment Solutions Programme (NE/P011160/1). MC acknowledges support from NERC National Capability project Climate Linked Atlantic Sector Science Programme (CLASS). 


\section{REFERENCES}

Allen, P. (2017). Sediment Routing Systems: The Fate of Sediment from Source to Sink. Cambridge, MA: Cambridge University Press. doi: 10.1017/9781316135754

Aloisi, G., Bouloubassi, I., Heijs, S. K., Pancost, R. D., Pierre, C., Damsté, J. S. S., et al. (2002). CH4-consuming microorganisms and the formation of carbonate crusts at cold seeps. Earth Planet. Sci. Lett. 203, 195-203. doi: 10.1016/S0012-821X(02)00878-6

Anderson, R. Y. (1982). A long geoclimatic record from the Permian. J. Geophys. Res. 87, 7285-7294. doi: 10.1029/JC087iC09p07285

Armitage, J. J., Duller, R. A., Whittaker, A. C., and Allen, P. A. (2011). Transformation of tectonic and climatic signals from source to sedimentary archive. Nat. Geosci. 4, 231-235. doi: 10.1038/ngeo1087

Armitage, J. J., Dunkley Jones, T., Duller, R. A., Whittaker, A. C., and Allen, P. A. (2013). Temporal buffering of climate-driven sediment flux cycles by transient catchment response. Earth Planet. Sci. Lett. 369-370, 200-210, doi: 10.1016/j.epsl.2013.03.020

Armitage, P. J., Worden, R. H., Faulkner, D. R., Aplin, A. C., Butcher, A. R., and Iliffe, J. (2010). Diagenetic and sedimentary controls on porosity in lower carboniferous fine-grained lithologies, krechba field, algeria: a petrological study of a caprock to a carbon capture site. Marine Petroleum Geol. 27, 1395-1410. doi: 10.1016/j.marpetgeo.2010.03.018

Azpiroz-Zabala, M., Cartigny, M. J. B., Talling, P. J., Parsons, D. R., Sumner, E. J., Clare, M. A., et al. (2017). Newly recognized turbidity current structure can explain prolonged flushing of submarine canyons. Sci. Adv. 3:e1700200. doi: $10.1126 /$ sciadv. 1700200

Baas, J. H., Best, J. L., and Peakall, J. (2016). Predicting bedforms and primary current stratification in cohesive mixtures of mud and sand. J. Geolo. Soc. 173, 12-45. doi: 10.1144/jgs2015-024

Bahr, A., Jiménez-Espejo, F. J., Kolasinac, N., Grunert, P., Hernández-Molina, F. J., Röhl, U., et al. (2014). Deciphering bottom current velocity and paleoclimate signals from contourite deposits in the Gulf of Cádiz during the last $140 \mathrm{kyr}$ : an inorganic geochemical approach. Geochem. Geophys. Geosyst. 15, 3145-3160. doi: 10.1002/2014GC005356

Bhattacharya, J. P., Copeland, P., Lawton, T. F., and Holbrook, J. (2016). Estimation of source area, river paleo-discharge, paleoslope, and sediment budgets of linked deep-time depositional systems and implications for hydrocarbon potentia. Earth Sci. Rev. 153, 77-110. doi: 10.1016/j.earscirev.2015.10.013

Bosence, D., Gibbons, K., Le Heron, D. P., Morgan, W. A., Pritchard, T., and Vining, B. A. (2015). "Microbial carbonates in space and time: introduction,"in Microbial Carbonates in Space and Time: Implications for Global Exploration and Production. Geological Society, Vol. 418, eds D. Bosence, K. Gibbons, D. P. Le Heron, W. A. Morgan, T. Pritchard, and B. A. Vining (London:Special Publications), 1-15.

Braun, J., Voisin, C., Gourlan, A. T., and Chauvel, C. (2015). Erosional response of an actively uplifting mountain belt to cyclic rainfall variations. Earth Surf. Dynam. 3, 1-14. doi: 10.5194/esurf-3-1-2015

Buckley, S. J., Howell, J. A., Schwarz, E., Terlaky, V., and Arnott, R. W. (2010). Combining aerial photogrammetry and terrestrial lidar for reservoir analog modeling. Photogrammet. Eng. Remote Sens. 76, 953-963. doi: 10.14358/PERS.76.8.953

Carrapa, B. (2010). Resolving tectonic problems by dating detrital minerals. Geology 38, 191-192. doi: 10.1130/focus022010.1

Carter, L., Gavey, R., Talling, P. J., and Liu, J. T. (2014). Insights into submarine geohazards from breaks in subsea telecommunication cables. Oceanography 27, 58-67. doi: 10.5670/oceanog.2014.40

Castelltort, S., and Van Den Driessche, J. (2003). How plausible are high-frequency sediment supply-driven cycles in the stratigraphic record? Sediment. Geol. 157, 3-13. doi: 10.1016/S0037-0738(03)00066-6

Cattaneo, A., and Steel, R. J. (2003). Transgressive deposits: a review of their variability. Earth-Sci. Rev. 62, 187-228. doi: 10.1016/S0012-8252(02) 00134-4

Cavanagh, A. J., Haszeldine, R. S., and Blunt, M. J. (2010). Open or closed? a discussion of the mistaken assumptions in the economides pressure analysis of carbon sequestration. J. Petrol. Sci. Eng. 74, 107-110. doi: $10.1016 /$ j.petrol.2010.08.017
Chamberlain, E. L., Törnqvist, T. E., Shen, Z., Mauz, B., and Wallinga, J. (2018). Anatomy of mississippi delta growth and its implications for coastal restoration. Sci. Adv. 4:eaar4740. doi: 10.1126/sciadv.aar4740

Clift, P. D. (2006). Controls on the erosion of cenozoic Asia and the flux of clastic sediment to the ocean. Earth Planet. Sci. Lett. 241, 571-580. doi: 10.1016/j.epsl.2005.11.028

Cobain, S. L., Hodgson, D. M., Peakall, J., Wignall, P. B., and Cobain, M. R. D. (2018). A new macrofaunal limit in the deep biosphere revealed by extreme burrow depths in ancient sediments. Sci. Rep. 8:261. doi: 10.1038/s41598-017-18481-w

Collins, D. B. G. (2004). Modeling the effects of vegetation-erosion coupling on landscape evolution. J. Geophys. Res. 109:F0. doi: 10.1029/2003JF000028

Courtene-Jones, W., Quinn, B., Gary, S. F., Mogg, A. O. M., and Narayanaswamy, B. E. (2017). Microplastic pollution identified in deep-sea water and ingested by benthic invertebrates in the rockall trough, North Atlantic Ocean. Environ. Pollut. 231, 271-280. doi: 10.1016/j.envpol.2017.08.026

Covault, J. A., Romans, B. W., Graham, S. A., Fildani, A., and Hilley, G. E. (2011). Terrestrial source to deep-sea sink sediment budgets at high and low sea levels: insights from tectonically active Southern California. Geology 39, 619-622. doi: $10.1130 / \mathrm{G} 31801.1$

Cummings, J. P., and Hodgson, D. M. (2011). An agrichnial feeding strategy for deep-marine paleogene ophiomorpha group trace fossils. Palaios 26, 212-224. doi: 10.2110/palo.2010.p10-098r

De Vleeschouwer, D., Boulvain, F., Da Silva, A. C., Pas, D., Labaye, C., Claeys, P. (2015). "The astronomical calibration of the Givetian (Middle Devonian) timescale (Dinant Synclinorium, Belgium)," in Magnetic Susceptibility Application: A Window onto Ancient Environments and Climatic Variations, Vol. 414, eds A. C. Da Silva, M. T. Whalen, J. Hladil, L. Chadimova, D. Chen, S. Spassov, F. Boulvain, and X. Devleeschouwer (London: Geological Society), 245-256.

Dewers, T., Eichhubl, P., Ganis, B., Gomez, S., Heath, J., Jammoul, M., et al. (2018). Heterogeneity, pore pressure, and injectate chemistry: control measures for geologic carbon storage. Int. J. Greenhouse Gas Control 68, 203-215. doi: 10.1016/j.ijggc.2017.11.014

Dietrich, W. E., and Perron, J. T. (2006). The search for a topographic signature of life. Nature 439, 411-418. doi: 10.1038/nature04452

Dowey, P. J., Hodgson, D. M., and Worden, R. H. (2012). Pre-requisites, processes, and prediction of chlorite grain coatings in petroleum reservoirs: a review of subsurface examples. Marine Petrol. Geol. 32, 63-75. doi: 10.1016/j.marpetgeo.2011.11.007

Ellis, D., and Ellis, K. (1994). Very deep STD. Marine Pollut. Bull. 28, 472-476. doi: 10.1016/0025-326X(94)90519-3

Ericson, J. P., Vörösmarty, C. J., Dingman, S. L., Ward, L. G., and Meybeck, M. (2006). Effective sea-level rise and deltas: causes of change and human dimension implications. Global Planet. Change 50, 63-82. doi: 10.1016/j.gloplacha.2005.07.004

Forzoni, A., Storms, J. E., Whittaker, A. C., and de Jager, G. (2014). Delayed delivery from the sediment factory: modeling the impact of catchment response time to tectonics on sediment flux and fluvio-deltaic stratigraphy. Earth Surf. Process. Landforms 39, 689-704. doi: 10.1002/esp.3538

Fosdick, J. C., Grove, M., Graham, S. A., Hourigan, J. K., Lovera, O., and Romans, B. W. (2015). Detrital thermochronologic record of burial heating and sediment recycling in the magallanes foreland basin, patagonian andes. Basin Res. 27, 546-572. doi: 10.1111/bre.12088

Galy, V., France-Lanord, C., Beyssac, O., Faure, P., Kudrass, H., and Palhol, F. (2007). Efficient organic carbon burial in the Bengal fan sustained by the Himalayan erosional system. Nature 450:407. doi: 10.1038/nature06273

Gill, J. C., and Malamud, B. D. (2016). Hazard interactions and interaction networks (cascades) within multi-hazard methodologies. Earth Syst. Dynam. 7, 659-679. doi: 10.5194/esd-7-659-2016

Godard, V., Tucker, G. E., Burch Fisher, G., Burbank, D. W., and Bookhagen, B. (2013). Frequency-dependent landscape response to climatic forcing. Geophys. Res. Lett. 40, 859-863. doi: 10.1002/grl.50253

Guillocheau, F., Rouby, D., Robin, C., Helm, C., and Rolland, N. (2012). Quantification and causes of the terrigeneous sediment budget at the scale of a continental margin: a new method applied to the Namibia-South Africa margin. Basin Res. 24, 3-30. doi: 10.1111/j.1365-2117.2011.00511.x 
Gwiazda, R., Paull, C. K., Ussler, I. I. I. W., and Alexander, C. R. (2015). Evidence of modern fine-grained sediment accumulation in the Monterey Fan from measurements of the pesticide DDT and its metabolites. Marine Geol. 363, 125-133. doi: 10.1016/j.margeo.2015.02.006

Hansen, L. A., Callow, R. H., Kane, I. A., Gamberi, F., Rovere, M., Cronin, B. T., et al. (2015). Genesis and character of thin-bedded turbidites associated with submarine channels. Marine Petrol. Geol. 67, 852-879. doi: 10.1016/j.marpetgeo.2015.06.007

Hawie, N., Deschamps, R., Granjeon, D., Nader, F. H., Gorini, C., Müller, C., et al. (2017). Multi-scale constraints of sediment source to sink systems in frontier basins: a forward stratigraphic modelling case study of the Levant region. Basin Res. 29, 418-445. doi: 10.1111/bre.12156

Hibbert, F. D., Rohling, E. J., Dutton, A., Williams, F. H., Chutcharavan, P. M., Zhao, C., et al. (2016). Coral indicators of past sea-level change: a global repository of U-series dated benchmarks. Q. Sci. Rev. 145, 1-56. doi: 10.1016/j.quascirev.2016.04.019

Hilgen, F., Brinkhuis, H., and Zachariasse, W. J. (2006). Unit stratotypes for global stages: the neogene perspective. Earth-Sci. Rev. 74, 113-125. doi: 10.1016/j.earscirev.2005.09.003

Hinnov, L. A., and Hilgen, F. J. (2012). Chapter 4 - Cyclostratigraphy and Astrochronology, in the Geologic Time Scale. Boston, MA: Elsevier, 63-83. doi: 10.1016/B978-0-444-59425-9.00004-4

Hodgson, D. M., Kane, I. A., Flint, S. S., Brunt, R. L., and Ortiz-Karpf, A. (2016). Time-transgressive confinement on the slope and the progradation of basinfloor fans: implications for the sequence stratigraphy of deep-water deposits. J. Sediment. Res. 86, 73-86. doi: 10.2110/jsr.2016.3

Jaeger, J. M., and Koppes, M. N. (2016). The role of the cryosphere in source-tosink systems. Earth-Sci. Rev. 153, 43-76 doi: 10.1016/j.earscirev.2015.09.011

Jerolmack, D. J., and Paola, C. (2010). Shredding of environmental signals by sediment transport. Geophys. Res. Lett. 37, 1-5. doi: 10.1029/2010GL044638

Jones, D. O., Walls, A., Clare, M., Fiske, M. S., Weiland, R. J., O’Brien, R., et al. (2014). Asphalt mounds and associated biota on the Angolan margin. Deep Sea Res. Part I 94, 124-136. doi: 10.1016/j.dsr.2014.08.010

Lai, H., Fang, H., Huang, L., He, G., and Reible, D. (2018). A review on sediment bioflocculation: dynamics, influencing factors and modeling. Sci. Total Environ. 642, 1184-1200. doi: 10.1016/j.scitotenv.2018.06.101

Lawton, T. F. (2014). Small grains, big rivers, continental concepts. Geology 42, 639-640. doi: 10.1130/focus072014.1

Leithold, E. L., Blair, N. E., and Wegmann, K. W. (2016). Source-to-sink sedimentary systems and global carbon burial: a river runs through it. Earth Sci. Rev. 153, 30-42. doi: 10.1016/j.earscirev.2015.10.011

Lichtman, I. D., Baas, J. H., Amoudry, L. O., Thorne, P. D., Malarkey, J., Hope, J. A., et al. (2018). Bedform migration in a mixed sand and cohesive clay intertidal environment and implications for bed material transport predictions. Geomorphology 315, 17-32. doi: 10.1016/j.geomorph.2018.04.016

Lin, H., Zhang, M., Wang, F., Meng, F., Liao, B. Q., Hong, H., et al. (2014). A critical review of extracellular polymeric substances (EPSs) in membrane bioreactors: characteristics, roles in membrane fouling and control strategies. J. Membrane Sci. 460, 110-125. doi: 10.1016/j.memsci.2014.02.034

Lisle, J. T., and Robbins, L. L. (2016). Viral lysis of photosynthesizing microbes as a mechanism for calcium carbonate nucleation in seawater. Front. Microbiol. 7:1958 doi: $10.3389 /$ fmicb. 2016.01958

Macdonald, R. W., and Bewers, J. M. (1996). Contaminants in the arctic marine environment: priorities for protection. ICES J. Mar. Sci. 53, 537-563. doi: 10.1006/jmsc. 1996.0077

Maher, B. A. (2016). Palaeoclimatic records of the loess/palaeosol sequences of the Chinese loess plateau. Q. Sci. Rev. 154, 23-84. doi: 10.1016/j.quascirev.2016.08.004

Malarkey, J., Baas, J. H., Hope, J. A., Aspden, R. J., Parsons, D. R., Peakall, J., et al. (2015). The pervasive role of biological cohesion in bedform development. Nat. Commun. 6:6257. doi: 10.1038/ncomms7257

Màngano, M. G., Buatois, L. A., Wilson, M., and Droser, M. (2016). "The Great Ordovician biodiversification event," in The Trace Fossil Record of Major Evolutionary Events, Volume 1: Precambrian and Paleozoic. Topics in Geobiology, Vol. 39, eds M. G. Màngano and L. A. Buatois (Springer), 127-156.

Marshall, N., Zeeden, C., Hilgen, F., and Krijgsman, W. (2017). Milankovitch cycles in an equatorial delta from the miocene of borneo. Earth Planet. Sci. Lett. 472, 229-240. doi: 10.1016/j.epsl.2017.04.015
Mason, C. C., and Romans, B. W. (2018). Climate-driven unsteady denudation and sediment flux in a high-relief unglaciated catchment-fan using $26 \mathrm{Al}$ and 10Be: Panamint Valley, California. Earth Planet. Sci. Lett. 492, 130-143 doi: $10.1016 /$ j.epsl.2018.03.056

Mauz, B., Hijma, M. P., Amorosi, A., Porat, N., Galili, E., and Bloemendal, J. (2013). Aeolian beach ridges and their significance for climate and sea level: concept and insight from the Levant coast (East Mediterranean). Earth-Sci. Rev. 121, 31-54. doi: 10.1016/j.earscirev.2013.03.003

Mellett, C. L., Hodgson, D. M., Lang, A., Mauz, B., Selby, I., and Plater, A. J. (2012). Preservation of a drowned gravel barrier complex: a landscape evolution study from the north-eastern English channel. Marine Geol. 315, 115-131. doi: 10.1016/j.margeo.2012.04.008

Moernaut, J., Daele, M. V., Heirman, K., Fontijn, K., Strasser, M., Pino, M., et al. (2014). Lacustrine turbidites as a tool for quantitative earthquake reconstruction: new evidence for a variable rupture mode in south central Chile. J. Geophys. Res. 119, 1607-1633. doi: 10.1002/2013JB010738

Murphy, S. F., McCleskey, R. B., Martin, D. A., Writer, J. H., and Ebel, B. A. (2018). Fire, flood, and drought: extreme climate events alter flow paths and stream chemistry. J. Geophys. Res. 123, 2513-2526. doi: 10.1029/2017JG004349

Murray, J. M., Meadows, A., and Meadows, P. S. (2002). Biogeomorphological implications of microscale interactions between sediment geotechnics and marine benthos: a review. Geomorphology 47, 15-30. doi: 10.1016/S0169-555X(02)00138-1

Näkki, P., Setälä, O., and Lehtiniemi, M. (2017). Bioturbation transports secondary microplastics to deeper layers in soft marine sediments of the northern Baltic Sea. Marine Pollut. Bull. 119, 255-261. doi: 10.1016/j.marpolbul.2017. 03.065

Needham, S. J., Worden, R. H., and McIlroy, D. (2005). Experimental production of clay rims by macrobiotic sediment ingestion and excretion processes. $J$. Sediment. Res. 75, 1028-1037. doi: 10.2110/jsr.2005.078

Owens, J. D., Lyons, T. W., and Lowery, C. M. (2018). Quantifying the missing sink for global organic carbon burial during a cretaceous oceanic anoxic event. Earth Planet. Sci. Lett. 499, 83-94. doi: 10.1016/j.epsl.2018. 07.021

Pancost, R. (2017). Climate change narratives. Nat. Geosci. 10, 466-468. doi: 10.1038/ngeo2981

Parkes, R. J., Cragg, B. A., and Wellsbury, P. (2000). Recent studies on bacterial populations and processes in subseafloor sediments: a review. Hydrogeol. J. 8, 11-28. doi: 10.1007/PL00010971

Payros, A., and Martínez-Braceras, N. (2014). Orbital forcing in turbidite accumulation during the eocene greenhouse interval. Sedimentology 61, 1411-1432. doi: 10.1111/sed.12113

Pelling, M., and Uitto, J. I. (2001). Small island developing states: natural disaster vulnerability and global change. Global Environ. Change Part B. 3, 49-62. doi: 10.1016/S1464-2867(01)00018-3

Perri, E., Tucker, M. E., Słowakiewicz, M., Whitaker, F., Bowen, L., and Perrotta, I. D. (2018). Carbonate and silicate biomineralization in a hypersaline microbial mat (Mesaieed sabkha, Qatar): roles of bacteria, extracellular polymeric substances and viruses. Sedimentology 65, 1213-1245. doi: 10.1111/sed.12419

Picot, M., Droz, L., Marsset, T., Dennielou, B., and Bez, M. (2016). Controls on turbidite sedimentation: insights from a quantitative approach of submarine channel and lobe architecture (Late Quaternary Congo Fan). Marine Petrol. Geol. 72, 423-446. doi: 10.1016/j.marpetgeo.2016.02.004

Ramirez-Llodra, E., Trannum, H. C., Evenset, A., Levin, L. A., Andersson, M., Finne, T. E., et al. (2015). Submarine and deep-sea mine tailing placements: a review of current practices, environmental issues, natural analogs and knowledge gaps in Norway and internationally. Marine Pollut. Bull. 97, 13-35. doi: 10.1016/j.marpolbul.2015.05.062

Richardson, J. C., Hodgson, D. M., Paton, D., Craven, B., Rawcliffe, A., and Lang, A. (2017). Where is my sink? Reconstruction of landscape development in southwestern Africa since the Late Jurassic. Gondwana Res. 45, 43-64. doi: 10.1016/j.gr.2017.01.004

Rockström, J., Schellnhuber, H. J., Hoskins, B., Ramanathan, V., Schlosser, P., Brasseur, G. P., et al. (2016). The world's biggest gamble. Earth's Fut. 4, 465-470. doi: 10.1002/2016EF000392

Roering, J. J., Marshall, J., Booth, A. M., Mort, M., and Jin, Q. (2010). Evidence for biotic controls on topography and soil production. Earth Planet. Sci. Lett. 298, 183-190. doi: 10.1016/j.epsl.2010.07.040 
Romans, B. W., Castelltort, S., Covault, J. A., Fildani, A., and Walsh, J. P. (2016). Environmental signal propagation in sedimentary systems across timescales. Earth-Sci. Rev. 153, 7-29. doi: 10.1016/j.earscirev.2015.07.012

Sadler, P. (1981). Sediment accumulation rates and the completeness of stratigraphic sections. J. Geol. 89, 569-584. doi: 10.1086/628623

Sadler, P. M., and Jerolmack, D. J. (2014). "Scaling laws for aggradation, denudation and progradation rates: the case for time-scale invariance at sediment sources and sinks," in Strata and Time: Probing the Gaps in Our Understanding. Geological Society, Vol. 404, eds D. G. Smith, R. J. Bailey, P. M. Burgess, and A. J. Fraser (London: Special Publications), 69-88.

Schaller, M., Ehlers, T. A., Lang, K. A. H., Schmid, M., and Fuentes-Espoz, J. P. (2018). Addressing the contribution of climate and vegetation cover on hillslope denudation, chilean coastal cordillera $\left(26^{\circ}-38^{\circ} \mathrm{S}\right)$. Earth Planet. Sci. Lett. 489, 111-122. doi: 10.1016/j.epsl.2018.02.026

Schillereff, D. N., Chiverrell, R. C., Macdonald, N., and Hooke, J. M. (2014). Flood stratigraphies in lake sediments: a review. Earth-Sci. Rev. 135, 17-37. doi: 10.1016/j.earscirev.2014.03.011

Schlunegger, F., and Castelltort, S. (2016). Immediate and delayed signal of slab breakoff in Oligo/Miocene Molasse deposits from the European Alps. Sci. Rep. 6:3. doi: 10.1038/srep31010

Sheng, G. P., Yu, H. Q., and Li, X. Y. (2010). Extracellular polymeric substances (EPS) of microbial aggregates in biological wastewater treatment systems: a review. Biotechnol. Adv. 28, 882-894. doi: 10.1016/j.biotechadv.2010.08.001

Sømme, T. O., Helland-Hansen, W., Martinsen, O. J., and Thurmond, J. B. (2009). Relationships between morphological and sedimentological parameters in source-to-sink systems: a basis for predicting semiquantitative characteristics in subsurface systems. Basin Res. 21, 361-387. doi: 10.1111/j.1365-2117.2009.00397.x

Stakes, D. S., Orange, D., Paduan, J. B., Salamy, K. A., and Maher, N. (1999). Coldseeps and authigenic carbonate formation in Monterey Bay, California. Marine Geol. 159, 93-109. doi: 10.1016/S0025-3227(98)00200-X

Steffen, W., Broadgate, W., Deutsch, L., Gaffney, O., and Ludwig, C. (2015). The trajectory of the Anthropocene: the great acceleration. Anthropocene Rev. 2, 81-98. doi: 10.1177/2053019614564785

Stevenson, C. J., Feldens, P., Georgiopoulou, A., Schönke, M., Krastel, S., Piper, D. J. W., et al. (2018). Reconstructing the sediment concentration of a giant submarine gravity flow. Nat. Commun. 9:e2616. doi: 10.1038/s41467-018-05042-6

Sumner, E. J., Siti, M. I., McNeill, L. C., Talling, P. J., Henstock, T. J., Wynn, R. B., et al. (2013). Can turbidites be used to reconstruct a paleoearthquake record for the central Sumatran margin? Geology 41, 763-766. doi: 10.1130/G34298.1

Syvitski, J. P., and Kettner, A. (2011). Sediment flux and the anthropocene. Philosophi. Transac. Royal Soc. A. 369, 957-975. doi: 10.1098/rsta.2010.0329
Syvitski, J. P., Vörösmarty, C. J., Kettner, A. J., and Green, P. (2005). Impact of humans on the flux of terrestrial sediment to the global coastal ocean. Science 308, 376-380. doi: 10.1126/science.1109454

Tambach, T. J., Koenen, M., Wasch, L. J., and van Bergen, F. (2015). Geochemical evaluation of $\mathrm{CO} 2$ injection and containment in a depleted gas field. Int. J. Greenhouse Gas Control 32, 61-80. doi: 10.1016/j.ijggc.2014.10.005

Terry, J. P., and Goff, J. R. (2012). “The special vulnerability of Asia-Pacific islands to natural hazards," in Natural Hazards in the Asia-Pacific Region: Recent Advances and Emerging Concepts. Geological Society, Vol. 361, eds J. P. Terry and Goff J. R (London: Special Publications), 3-5.

Ulloa, H., Iroumé, A., Picco, L., Korup, O., Lenzi, M. A., Mao, L., et al. (2015). Massive biomass flushing despite modest channel response in the Rayas River following the 2008 eruption of Chaitén volcano, Chile: Geomorphology 250, 397-406. doi: 10.1016/j.geomorph.2015.09.019

UNSDGs (2015). United Nations Sustainable Development Goals. Available online at: http://www.un.org/sustainabledevelopment/sustainable-developmentgoals/

Urlaub, M., Geersen, J., Krastel, S., and Schwenk, T. (2018). Diatom ooze: Crucial for the generation of submarine mega-slides? Geology 46, 331-334. doi: 10.1130/G39892.1

Vrana, B., Allan, I. J., Greenwood, R., Mills, G. A., Dominiak, E., Svensson, K., et al. (2005). Passive sampling techniques for monitoring pollutants in water. TrAC Trends Anal. Chem. 24, 845-868. doi: 10.1016/j.trac.2005. 06.006

Wooldridge, L. J., Worden, R. H., Griffiths, J., Thompson, A., and Chung, P. (2017). Biofilm origin of clay-coated sand grains. Geology 45, 875-878 doi: 10.1130/G39161.1

Zalasiewicz, J., Waters, C. N., do Sul, J. A. I., Corcoran, P. L., Barnosky, A. D., Cearreta, A., et al. (2016). The geological cycle of plastics and their use as a stratigraphic indicator of the anthropocene. Anthropocene 13, 4-17. doi: $10.1016 /$ j.ancene.2016.01.002

Conflict of Interest Statement: The authors declare that the research was conducted in the absence of any commercial or financial relationships that could be construed as a potential conflict of interest.

Copyright (C) 2018 Hodgson, Bernhardt, Clare, Da Silva, Fosdick, Mauz, Midtkandal, Owen and Romans. This is an open-access article distributed under the terms of the Creative Commons Attribution License (CC BY). The use, distribution or reproduction in other forums is permitted, provided the original author(s) and the copyright owner(s) are credited and that the original publication in this journal is cited, in accordance with accepted academic practice. No use, distribution or reproduction is permitted which does not comply with these terms. 